\title{
ASSESSING THE ADEQUACY OF PENSION SYSTEMS IN GEORGIA AND EUROPE
}

\author{
MAKA GHANIASHVILI \\ PhD student, \\ Ivane Javakhishvili Tbilisi State University, Georgia \\ maka.ghaniashvili@tsu.ge
}

Abstract. For several decades, pension systems across the world have been undergoing reforms. The main reasons for this are demographic changes and increasing life expectancy. As life expectancy increases and the birth rate decreases, more people retire than are added to the workforce. To make these reforms more effective and ensure that they are based on the best benchmarks, the European Union (EU) has introduced the Open Method of Coordination (OMC) in the field of pensions. Pension system reform is on its way in Georgia since 2019, January. OMC evaluates pensions systems in terms of the three main objectives: adequacy, sustainability, and modernization of pensions. Our methodology is based on multivariate statistical analysis, and employs synthetic indicators for adequacy objectives, in case of Georgia and 27 EU countries, in the years 2010, 2015 and 2018. The article contributes to the existing literature on pension reforms through investigation of the convergence of EU27 and Georgia pension systems in terms of one of the OMC objectives, in order to evaluate the adequacy of the pension systems.

\section{KEYWORDS: PENSION SYSTEM, PENSION ADEQUACY, REFORM.}

For citation: Ghaniashvili, M., (2020). Assessing the Adequacy of Pension Systems in Georgia and Europe. Globalization and Business, 10. 198-203. https://doi.org/10.35945/gb.2020.10.025

\section{INTRODUCTION}

There is a great deal of discussion among scientists about evaluating the effectiveness of the pension system, as well as any other fundamental issue. What determines the adequacy of the pension system and what methods can be used to measure its effectiveness?

No matter how we define the pension system, its goals or functions, there is no doubt that the main purpose of the system is to provide a retiree with an adequate income at retirement age. Traditional studies on the degree of achievement of the mentioned goal were usually limited to the study of the level of pension issued. This is a one-dimensional approach to assessing the adequacy of the pension system. In the study below, we discuss a multidimensional approach to the issue based on the macro-functioning of the pension system, namely, the distribution of income throughout the life cycle. A similar approach to the evaluation of pension systems has been introduced in European countries under the EU framework policy - Open Method of Coordination (OMC). The OMC is an EU policy framework, which, although doesn't represent regulatory norms at the legislative level, however, it aims to introduce the best practices in this or that area of policy in the Member States (including the management of pension systems) and to facilitate the implementation of policies coordinated by governments.

One of the key macro-functional aspects of the pension system is the distribution of GDP between the working-age generation and the rest of the population, including retirees. This means that the income of a current retiree depends, on the one hand, on the level of income allocation over the life cycle and, on the other hand, on current GDP and its redistribution between generations. This must be taken into account when assessing the adequacy of the pension system. Assessing the adequacy of the pension system also requires indicators for measuring income, poverty and income inequality, and measurement in the gender context of poverty.

\section{LITERATURE REVIEW}

Over the last few decades, in parallel with adequacy in assessing the pension system, the issue of efficiency came to the fore.

Part of the scholars consider the efficiency of the pension system as a key feature for evaluating the system. However, it is very difficult to find a proper explanation for effectiveness of the pension system at macro level. Among the scholars who offer research on this subject are Hayek (1960); Boldrin and Montes (2009); Breyer and Kolmar (2002); Fenge and von Weizsa"cker (2010) and Le Garrec (2014). Many of them study pension systems at a theoretical level. For exmple Weizsacker (2003) compares pension systems based on Hayek, Bismarck and Beveridge models and tries 
to find a better one between them. Ayede (2010) studies the behavior of older people within the pay-as-you-go system. Breyer and Kolmar investigate labor market responses during the pay-as-you-go (PAYG) system. Wrede (1998) investigates the issues of paretoeffectiveness of the PAYG system. Hansen and Lonstrup (2009) analyze what might be the optimal retirement age for both women and men.

As for adequacy, its extensive discussion has been proposed by Hurd and Rohwedder (2008). They believe that pension adequacy should be considered primarily in terms of individual well-being and that income expressed in absolute or relative terms (e.g., replacement ratio) does not constitute a proper measure. When discussing the adequacy of the pension system, it is also important to determine the norm of savings in the pension system (Chutlashvili, 2018) and social analysis of the system (Urotadze, 2016). Problems of demographic aging and optimization of the pension system are being studied by Archvadze I. and Archvadze N., (2012).

Borella and Fornero (2009) conducted a comparative analysis of the adequacy of the pension systems of 12 countries. Their study includes comprehensive replacement rates (CORE). It is based on a ratio of the standard of living after retirement to the standard of living, a person had before retirement. However, they focus on only one dimension of pension adequacy, as CORE applies only to the optimal rate of uniform distribution of consumption.

A review of empirical studies makes it clear that a onedimensional approach is mainly used to assess the adequacy of the pension system, and this dimension is, in most cases, a replacement coefficient.

\section{ADEQUACY OF THE PENSION SYSTEM}

For the EU OMC Framework Policy, the first objective of the pension system is to determine the adequacy of pensions, which includes the following steps:

- Avoiding social exclusion, which includes the following: «Older people are not at risk of poverty and can receive a certain standard of living; "They share the economic prosperity of the country and, consequently, can participate in public, social and cultural life.»

- Ability to maintain a standard of living: The pension system (whether public or private) should provide all individuals with a pension that will enable them to maintain a certain standard of living after retirement.»

- Promoting solidarity between generations and within generations.

The approaches of the World Bank and the European Commission to determine the adequacy of the pension system have basically the same objectives. At the same time, the European Commission names solidarity between the generations and within the generation as well, which can actually be considered, not as a goal, but as a tool to achieve another goal (prevention of social exclusion of the elderly). It should be noted that the goals of the pension systems set by both international organizations reflect a multidimensional approach to the adequacy of the pension system. It is true that they mainly focus on the amount of the pension (which should provide an adequate standard of living, at least above the poverty line), but they also emphasize the need for a fair distribution of income over the life cycle.

The Organization for Economic Co-operation and Development (OECD) believes that an adequate pension system is one that replaces an employeess income to a level that allows him or her to maintain the standard of living he or she had during his or her active working life before retiring (OECD 2013).

The International Labor Organization (ILO) states that the purpose of the pension system is to provide the retiree with an adequate standard of living beyond the poverty line for the rest of his or her life. Moreover, the pension system should be universal and not discriminatory in terms of gender (Grech 2013). The European Commission attributes this issue to the third group of OMC goals - the modernization of pension systems.

According to the OMC Framework Policy document, there are three main groups for evaluating the effectiveness of pension systems: adequacy indicators, sustainability indicators, and modernization indicators (Table \# 1).

\section{RESEARCH METHODOLOGY}

The study uses a method of quantitative analysis of pension systems developed by the Polish scientist Filip Chybalski (Filip Chybalski, 2016) which is particularly suitable for the macro scale of the pension system and considers its openness at the global level. The method is based on empirical research and statistics and allows to compare the pension systems of several countries or the pension systems of the same country in different periods. In the present study, we will focus on the first group of OMC objectives - the four variables of adequacy indicators. As for the indicators of sustainability and modernization group, we will discuss them in further studies.

The first phase of the research involves finding the statistical data given in Table \# 1 for the four indicators of Georgia and 27 countries of Europe for 2010, 2015 and 2018 ARP, ARR, MRI and S80 / S20 (see statistics in the appendices).

The next step is to transform the data. Of the four variables used, ARP and S80 / S20 have a destimative character (the lower the score the better it is); In the case of ARR and MRI indicators, on the contrary - the best pension systems are characterized by a high score of these indicators. So we transform the ARP and S80 / S20 variables with the following formula: $x_{i j}=\max x_{i j}-x_{i j}$

Where the obtained $x_{i j}$ value is the optimal value of the given (i) indicator for the (j) object.

Then we plot the interval between all indicators $[0,1]$ using the normalization formula.

In the last step, we convert the indexed indicators into a synthetic adequacy indicator using the following formula:

$$
A_{i j}=\frac{1}{4}\left(x A R P_{i j}+M R I_{i j}+A R R_{i j}+S 80 / S 20_{i j}\right)
$$


Table \# 1

\begin{tabular}{|c|c|}
\hline \multicolumn{2}{|r|}{ OMC Indicators } \\
\hline \multicolumn{2}{|r|}{ Adequacy Indicators } \\
\hline ARP & at-risk-of-poverty rate of pensioners \\
\hline MRI65+ & median relative income ratio of scepelderly people aged $65+$ \\
\hline ARR & aggregated replacement ratio \\
\hline S80/S20 & inequality of income distribution for people aged $65+$ \\
\hline \multicolumn{2}{|r|}{ Sustainability Indicators } \\
\hline PE/GDP & total current pension expenditures as \% of GDP \\
\hline EMP55-64 & employment rate of people aged $55-64$ \\
\hline DWL & duration of working life \\
\hline \multicolumn{2}{|r|}{ Moderniozation Indicators } \\
\hline dARP & gender difference in the at-risk-of-poverty rate of pensioners, $A R P_{\text {males }}-A R P_{\text {females }}$, optimal value - 0 \\
\hline dMRI & gender difference in the median relative income ratio, $M R I_{\text {males }}-M R I_{\text {females }}$, optimal value - 0 \\
\hline dARR & gender difference in the aggregated replacement ratio, $A R R_{\text {males }}-A R R_{\text {females }}$, optimal value - 0 \\
\hline
\end{tabular}

In the case of European countries, the indicators defined by the OMC policy are available on the Eurostat website. As for Georgia: In the case of APR indicator, we used UNICEF data. According to a UNICEF study, the pensioner poverty rate was $21.3 \%$ in 2010 , while in 2017 the ARP rate was $17.6 \%$ among the retirement generation. MRI - We calculated MRI indicator based on the World Bank data per capita net income and pension income ratio. As for the ARR index, it increased from $14 \%$ in 2010 to $19.1 \%$ in 2019.

We also calculated the values of the S80 / S20 indicator for Georgia based on the World Bank statistical database. The indicator shows the difference between the income of the richest $20 \%$ of the countrys population and the income of the poorest $20 \%$. The lower the rate the better it is. In addition, in the case of Georgia, it was difficult to find data on income inequality by age category. So we used the whole picture. Moreover, when comparing the data of the EU countries for the S80 / S20 indicator, the rates of the total population and the population aged $65+$ slightly or do not differ from each other. In the case of Georgia, the income inequality rate was 7.9 in 2010 and 6.6 in 2018, which means that inequality between income redistribution has decreased.

\section{RESEARCH RESULTS AND CONCLUSION}

Our research has revealed several trends (Table \#2):

If between 2010 and 2015 only 8 countries out of 27 European countries (Czech Republic, Germany, Estonia, Ireland, Latvia, Lithuania, Hungary and Sweden) changed the adequacy ratio of the pension system for the worse, from 2015 to 2018, the adequacy ratio of the pension system of the vast majority of European countries which we studied, deteriorated. The only exceptions in this case are Ireland, Romania and the United Kingdom and the pension system adequacy ratio in these countries has been improved over the three years since 2015. Indicators of Finland and Sweden remained unchanged. Based on the demographic picture mentioned at the beginning of the study, this is not surprising. That is why large-scale reforms of the pension systems became necessary, which was once again confirmed by the quantitative research we conducted.
Table \#2

\begin{tabular}{|l|c|c|c|}
\hline \multicolumn{1}{|c|}{ Country } & \multicolumn{3}{|c|}{ Pension system } \\
& Synthetic rates of adequacy by years \\
\hline & 2010 & 2015 & 2018 \\
\hline EU27 & 0.61 & 0.63 & 0.63 \\
\hline Belgium & 0.53 & 0.67 & 0.64 \\
\hline Czech Republic & 0.83 & 0.78 & 0.70 \\
\hline Denmark & 0.51 & 0.68 & 0.66 \\
\hline Germany & 0.61 & 0.60 & 0.53 \\
\hline Estonia & 0.61 & 0.39 & 0.32 \\
\hline Ireland & 0.61 & 0.53 & 0.54 \\
\hline Greece & 0.46 & 0.76 & 0.74 \\
\hline Spain & 0.46 & 0.79 & 0.65 \\
\hline France & 0.71 & 0.79 & 0.76 \\
\hline Italy & 0.61 & 0.73 & 0.65 \\
\hline Cyprus & 0.27 & 0.52 & 0.47 \\
\hline Latvia & 0.48 & 0.34 & 0.20 \\
\hline Lithuania & 0.68 & 0.46 & 0.30 \\
\hline Luxembourg & 0.89 & 0.93 & 0.76 \\
\hline Hungary & 0.97 & 0.87 & 0.77 \\
\hline Malta & 0.51 & 0.62 & 0.6 \\
\hline Netherlands & 0.76 & 0.78 & 0.7 \\
\hline Austria & 0,58 & 0.74 & 0.7 \\
\hline Poland & 0.69 & 0.78 & 0.71 \\
\hline Portugal & 0.41 & 0.64 & 0.55 \\
\hline Romania & 0.67 & 0.58 & 0.59 \\
\hline Slovenia & 0.53 & 0.64 & 0.61 \\
\hline Slovakia & 0.87 & 0.87 & 0.85 \\
\hline Finland & 0.60 & 0.69 & 0.69 \\
\hline Sweden & 0.73 & 0.66 & 0.66 \\
\hline The Great Britain & 0.41 & 0.59 & 0.75 \\
\hline Norway & 0.70 & 0.8 & 0.79 \\
\hline Georgia & 0.02 & 0.14 & 0.19 \\
\hline & & & \\
\hline
\end{tabular}

Source: Table data is based on the results of a quantitative survey conducted by the author. Data: eurostat; geostat.ge; nbg.gov.ge; world bank 
As for Georgia, in the case of our country, the adequacy rate is increasing, as the starting point is very low - in 2010 it was 0.02 points, in $2015-0.14$ and in $2018-0.19$. Not surprisingly, Georgia «s pension system is characterized by the lowest level of adequacy among the countries surveyed. Georgiass pension system is close to countries such as Cyprus, Estonia, Latvia, Lithuania and Malta in terms of adequacy.

Quantitative analysis of the pension system can identify the countries and, consequently, the pension systems that improve their pension adequacy ratios from year to year and

\section{Annex \#1}

\begin{tabular}{|l|c|c|c|c|}
\hline \multirow{2}{*}{ Country } & \multicolumn{4}{c|}{ Adequacy Indicators (2010) } \\
\cline { 2 - 5 } & ARP & MRI & ARR & S80/S20 \\
\hline EU27 & $12.8-$ & 0.89 & 0.53 & 3.99 \\
\hline Belgium & 16.1 & 0.75 & 0.46 & 3.70 \\
\hline Czech Republic & 6.6 & 0.82 & 0.54 & 2.38 \\
\hline Denmark & 16.6 & 0.71 & 0.44 & 3.60 \\
\hline Germany & 13.4 & 0.89 & 0.49 & 3.81 \\
\hline Estonia & 17.9 & 0.73 & 0.55 & 2.94 \\
\hline Ireland & 10.5 & 0.85 & 0.47 & 4.00 \\
\hline Greece & 19.0 & 0.84 & 0.42 & 4.13 \\
\hline Spain & 16.5 & 0.88 & 0.47 & 4.76 \\
\hline France & 7.5 & 0.98 & 0.65 & 3.39 \\
\hline Italy & 12.5 & 0.92 & 0.53 & 4.18 \\
\hline Cyprus & 39.1 & 0.65 & 0.37 & 4.72 \\
\hline Latvia & 19.6 & 0.78 & 0.47 & 3.83 \\
\hline Lithuania & 12.6 & 0.93 & 0.58 & 3.63 \\
\hline Luxembourg & 5.4 & 1.05 & 0.68 & 3.25 \\
\hline Hungary & 4.0 & 1.01 & 0.68 & 2.55 \\
\hline Malta & 17.9 & 0.81 & 0.44 & 3.72 \\
\hline Netherlands & 5.7 & 0.87 & 0.47 & 3.10 \\
\hline Austria & 15.5 & 0.90 & 0.57 & 4.21 \\
\hline Poland & 12.8 & 0.93 & 0.57 & 3.52 \\
\hline Portugal & 18.5 & 0.82 & 0.53 & 5.02 \\
\hline Romania & 12.9 & 0.97 & 0.64 & 4.17 \\
\hline Slovenia & 18.3 & 0.87 & 0.45 & 3.61 \\
\hline Slovakia & 6.7 & 0.83 & 0.61 & 2.32 \\
\hline Finland & 17.0 & 0.78 & 0.50 & 3.07 \\
\hline Sweden & 14.3 & 0.79 & 0.59 & 3.10 \\
\hline The Great Britain & 22.9 & 0.81 & 0.48 & 4.34 \\
\hline Iceland & 6.3 & 0.96 & 0.48 & 3.95 \\
\hline Norway & 0.85 & 0.50 & 2.83 \\
\hline
\end{tabular}

Source: Table data is based on the results of a quantitative survey conducted by the author.

Data: eurostat; geostat.ge; nbg.gov.ge; world bank. those countries in which, on the contrary, the situation has deteriorated in the period from 2010 to 2018. The example of successful and unsuccessful countries can be a useful experience and recommendation for Georgia.

Here we would like to remind you that the efficiency indicator does not provide a complete picture of the multidimensional evaluation of the pension system. Because adequacy is only one of the three groups of OMC framework policies. We will continue our research in the future to study the other indicators.

\section{Annex \#2}

\begin{tabular}{|l|c|c|c|c|}
\hline \multirow{2}{*}{ Country } & \multicolumn{4}{|c|}{ Adequacy Indicators (2015) } \\
\cline { 2 - 5 } & ARP & MRI & ARR & S80/S20 \\
\hline EU27 & 12.5 & 0.94 & 0.58 & 5.22 \\
\hline Belgium & 12.4 & 0.79 & 0.47 & 3.20 \\
\hline Czech Republic & 7.4 & 0.81 & 0.51 & 2.41 \\
\hline Denmark & 8.8 & 0.77 & 0.45 & 3.22 \\
\hline Germany & 17.0 & 0.87 & 0.46 & 3.96 \\
\hline Estonia & 40.1 & 0.62 & 0.43 & 3.45 \\
\hline Ireland & 15.7 & 0.88 & 0.37 & 4.09 \\
\hline Greece & 10.8 & 1.04 & 0.62 & 4.08 \\
\hline Spain & 10.2 & 1.01 & 0.66 & 4.31 \\
\hline France & 7.1 & 1.04 & 0.69 & 4.46 \\
\hline Italy & 11.0 & 0.99 & 0.66 & 4.51 \\
\hline Cyprus & 16.5 & 0.80 & 0.43 & 4.74 \\
\hline Latvia & 36.7 & 0.65 & 0.42 & 4.20 \\
\hline Lithuania & 27.6 & 0.73 & 0.46 & 4.20 \\
\hline Luxembourg & 5.8 & 1.08 & 0.80 & 3.48 \\
\hline Hungary & 5.8 & 1.01 & 0.65 & 2.99 \\
\hline Malta & 18.7 & 0.75 & 0.54 & 3.41 \\
\hline Netherlands & 6.2 & 0.89 & 0.52 & 3.05 \\
\hline Austria & 12.9 & 0.98 & 0.62 & 3.75 \\
\hline Poland & 11.1 & 0.99 & 0.62 & 3.48 \\
\hline Portugal & 14.4 & 0.92 & 0.62 & 4.96 \\
\hline Romania & 15.8 & 1.00 & 0.63 & 6.19 \\
\hline Slovenia & 15.9 & 0.90 & 0.46 & 3.55 \\
\hline Slovakia & 6.2 & 0.91 & 0.62 & 2.33 \\
\hline Finland & 13.5 & 0.81 & 0.52 & 3.13 \\
\hline Sweden & 17.2 & 0.79 & 0.57 & 3.30 \\
\hline The Great Britain & 18.3 & 0.88 & 0.50 & 4.19 \\
\hline Iceland & 7.3 & 0.82 & 0.53 & 3.49 \\
\hline Norway & 0.92 & 0.61 & 2.91 \\
\hline
\end{tabular}

Source: Table data is based on the results of a quantitative survey conducted by the author.

Data: eurostat; geostat.ge; nbg.gov.ge; world bank. 
Annex \#3

\begin{tabular}{|l|c|c|c|c|}
\hline \multirow{2}{*}{ Country } & \multicolumn{3}{|c|}{ Adequacy Indicators (2018) } \\
\cline { 2 - 5 } & ARP & MRI & ARR & S80/S20 \\
\hline EU27 & 15.2 & 0.91 & 0.57 & 4.12 \\
\hline Belgium & 14.1 & 0.78 & 0.47 & 3.06 \\
\hline Czech Republic & 14.2 & 0.74 & 0.51 & 2.51 \\
\hline Denmark & 9.3 & 0.78 & 0.45 & 3.20 \\
\hline Germany & 18.7 & 0.84 & 0.46 & 4.29 \\
\hline Estonia & 53.6 & 0.57 & 0.43 & 3.64 \\
\hline Ireland & 19.9 & 0.84 & 0.37 & 3.73 \\
\hline Greece & 8.7 & 1.01 & 0.62 & 3.86 \\
\hline Spain & 13.1 & 0.95 & 0.66 & 4.5 \\
\hline France & 7.3 & 1.04 & 0.69 & 4.1 \\
\hline Italy & 12.0 & 1.01 & 0.66 & 4.86 \\
\hline Cyprus & 21.5 & 0.8 & 0.43 & 4.55 \\
\hline Latvia & 48.9 & 0.58 & 0.42 & 5.07 \\
\hline Lithuania & 41.7 & 0.64 & 0.46 & 4.87 \\
\hline Luxembourg & 9.2 & 1.11 & 0.87 & 4.98 \\
\hline Hungary & 10 & 0.97 & 0.65 & 3.39 \\
\hline Malta & 23.7 & 0.72 & 0.54 & 3.1 \\
\hline Netherlands & 12 & 0.81 & 0.52 & 3.02 \\
\hline Austria & 13.1 & 0.95 & 0.62 & 3.76 \\
\hline Poland & 15 & 0.91 & 0.62 & 3.42 \\
\hline Portugal & 15.7 & 0.90 & 0.62 & 5.23 \\
\hline Romania & 19.5 & 0.90 & 0.63 & 4.46 \\
\hline Slovenia & 18.1 & 0.85 & 0.46 & 3.44 \\
\hline Slovakia & 7 & 0.90 & 0.62 & 2.31 \\
\hline Finland & 13 & 0.82 & 0.52 & 3.02 \\
\hline Sweden & 15.8 & 0.80 & 0.57 & 3.43 \\
\hline The Great Britain & 22.8 & 0.88 & 0.50 & 4.7 \\
\hline Norway & 7.8 & 0.91 & 0.61 & 2.87 \\
\hline & & & & \\
\hline
\end{tabular}

Source: Table data is based on the results of a quantitative survey conducted by the author. Data: eurostat; geostat.ge; nbg.gov.ge; world bank

\section{REFERENCES:}

Archvadze, I., \& Archvadze, N. (2012). Demographic aging of the population and problems of optimization of the pension system. Tbilisi: Meridian; (In Georgian)

lakobashvili, A. Europe for georgia - Design and Ideology of Pension Reform, 2018, http://eugeorgia.info/ka/articleblog/62/ sapensio-reformis-dizaini-da-ideologia/ (In Georgian)

Ibadoglu, G., Pension system in the Republic of Azerbaijan, National Parliamentary Library of Georgia, http://www.nplg.gov. ge/ (In Georgian) 
Papava, V., Georgian Economy, Intellect Publishing House, Tbilisi, 2015; (In Georgian)

Chutlashvili, A., Savings rate and changes in the pension system, Tbilisi State University, 2018, 577-581; (In Georgian)

Urotadze J., \& Ivane Javakhishvili Tbilisi State University, Faculty of Social and Political Sciences, Journal of Young Researchers http://jyr.tsu.ge/), \#3. 2016, E ISSN: 2346-7754, 63-64; (In Georgian)

Ayede, Y. (2010). Generational selfishness and social security: A time-inconsistency problem in parametric reforms of PAYG. Journal of Economic Policy Reform, 13(2), 179-190.

Bedianashvili, G., Gogiashvili, \& S., Pavliashvili, S. (2015), European Union, Georgia and Institional Environment of Competition. European Cooperation 5 (5), 9-23

Boldrin, M., \& Montes, A. (2009). Assessing the efficiency of public education and pensions. Journal of Population Economics, 22(2), 285-309.

Boldrin, M., Garriga, C., Peralta-Alva, A., \& \& Sánchez, J.M. (2020) Reconstructing the great recession, Federal Reserve Bank of St. Louis Review, 102(3), 271-311

Borella, M., \& Fornero, E. (2009). Adequacy of pension systems in Europe: An analysis based on com- prehensive replacement rates. ENEPRI Research Report No. 68. http://aei.pitt.edu/10967/1/1837

Breyer, F., \& Kolmar, M. (2002). Are national pension systems efficient if labor is (im)perfectly mobile? Journal of Public Economics, 83(3), 347-374.

Chybalski F. (2014). Financial stability of pension systems: A cross country analysis. In D. Stavarek \& P. Vodova (Eds.), Proceedings of the 14th international conference on finance and banking (pp. 150-158). Karvina: Silesian University.

European Commission (2003) Adequate and sustainable pensions, Luxembourg

Fenge, R., \& von Weizsä cker, J. (2010). Mixing Bismarck and child pension systems: An optimum taxation approach. Journal of Population Economics, 23(2), 805-823.

Fenge, R. , Peglow, F. (2018) , Decomposition of demographic effects on the german pension system, Journal of the Economics of Ageing, 2018, 12, pp. 61-76

Grech, A. (2013). How best to measure pension adequacy. Centre for analysis of social exclusion. London: London School of Economics.

Hayek, F. (1960). The constitution of liberty. Chicago: University of Chicago Press.

Hansen, C., \& Lonstrup, L. (2009). The optimal legal retirement age in OLG model with endogenous labour supply. Discussion papers on business and economics no. 5/2009.

Hurd M.D., \& Rohwedder S. (2008) 'The Adequacy of Economic Resources in Retirement', MRRC- Working Paper No. 2008184.

Marcinkiewicz, E., \& Chybalski, F. (2014). How to measure and compare pension expenditure in cross- country analyses? International Journal of Business \& Management, I, II (4), 43-59.

Jgerenaia E. Factors Affecting the exchange rate and the Peculiriaties of economics laws in Developing Countries (The Case of Georgia), Ecoforum

Le Garrec, G. (2014). Increased longevity and social security reform: Questioning the optimality of individual account when education matters. Journal of Population Economics. doi:10.1007/s00148-014- 0522-z.

Weizsacker, J. (2003). The Hayek Pension. An efficient minimum pension to complement the welfare state. CESifo working paper no. 1064.

Wrede, M. (1998). Pareto efficiency of the pay-as-you-go pension system in a three-period-OLG model. BERG working paper series 27, University of Bamberg.

OECD (2013). Pension at a glance: OECD and G20 indicators. OECD Publishing

https://www.europarl.europa.eu/EPRS/EPRS-AaG-542142-Open-Method-of-Coordination-FINAL.pdf

https://data.worldbank.org/indicator0.65/NY.ADJ.NNTY.PC.CD?locations=GE

www.geostat.ge

www.nbg.gov.ge

www.unicef.org

www.oecd.org

www.ec.europa.eu 